\title{
Fish and Plankton Biodiversity in the Kishoreganj Haor, Kishoreganj, Bangladesh
}

\author{
Ariful Islam ${ }^{1}$, S. Sanjib Basak ${ }^{1}$, Zakir Hossain $^{1}, *$ (]) \\ ${ }^{1}$ Bangladesh Agricultural University, Department of Fisheries Biology and Genetics, Mymensingh-2202, Bangladesh.
}

\section{Article History}

Received December 17, 2019

Accepted May 21, 2020

First Online May 22, 2020

\section{Corresponding Author \\ Tel.: +8809169116 \\ E-mail: zakir.fbg@bau.edu.bd}

\section{Keywords}

Climate change

Fishing pressure

Abundance

Haor

\begin{abstract}
Haor is a wetland environment considered as a rich diversified fisheries resource with important role on ecology, economy and social structure. The present study was conducted to evaluate the diversity of fish and plankton communities in the Kishoregonj haor, Kishoreganj, Bangladesh. Fish samples were collected from the fishers and fish landing station for taxonomic study from July 2017 to December 2018. Fish were identified through direct observation and using morphometric and meristic characteristics. A total of 23 genera of phytoplankton belonging to 4 classes were identified. A total 8 genera of Bacillariaophyceae, 9 genera of Chlorophyceae, 3 genera of Cyanophyceae and 3 genera of Euglenophyceae class were listed from the study area. In total 3 groups of zooplankton were identified, i.e. Phylum- Rotifera, OrderCladocera and Sub-class-Copepoda in Kishoreganj haor. In the present study, a total of 79 species of fishes belonging to 27 families under 9 orders were recorded. Cypriniformes was found as the most dominant order comprising 31 species followed by Siluriformes (21) and Perciformes (15). The result of this study showed that the fish and plankton diversity indices in the Kishoreganj haor are good even some fish species are gradually decreasing.
\end{abstract}

\section{Introduction}

Haor is a productive wetland ecosystem with a high environmental, economic and social value that is characterized by being a bowl-shaped depression covered by water almost six months in a year starting from the monsoon (Sarma et al. 2010). Haor ecosystem covers about $25 \%$ of the Northeastern part of Bangladesh. In addition, it is a mosaic of wetland habitats including rivers, streams and irrigation canals, large areas of seasonally flood plains and hundreds of haors and beels (Hussain et al., 2007). In seven districts of Bangladesh; Sylhet, Moulavibazar, Habiganj and Sunamganj in northeast, Netrokona and Kishoreganj in north central and Brahmanbaria in central eastern region of Bangladesh, a number of 423 haors comprising a surface area of about $8000 \mathrm{~km}^{2}$ are present (Miah, 2013). The three sides of haor region are surrounded by mountain ranges of India, with Meghalaya in north, Tripura and Mizoram in south, and Manipur and Assam in east.

The haor region is crisscrossed by numerous rivers coming down from the hills of India with huge amount of runoff water during monsoon, which ultimately falls into Meghna basin (Ahmed, 2012; Rabby et al., 2011). Usually water body in the haor region remains at zero level from January to March and then starts to increase and go down again during August (Sarma, 2010; Nowreen et al., 2015). Mostly, in June and July, the water level reaches the highest point (Salauddin and 
Islam, 2011). In addition, the rainfall in the haor region is comparatively higher than the other region of country. The average annual rainfall in the haor areas is 4130 $\mathrm{mm}$, which is almost twice higher than the country's average annual rainfall (Nowreen et al., 2015). The physical settings and hydrology of the haor region created countless opportunities as well as constraints for the inhabitants (Hanif et al., 2015).

Haor contains diverse types of floral and faunal diversity especially reptiles, birds, fish species, amphibians etc., which play an important role in the existence of haor ecosystem (Choudhury, 2016). According to Pandit et al. (2015) over 84 species of fish were reported to be commonly caught by local fishermen in the haor region. Islam et al. (2008) recorded 108 species under 29 families of 10 orders from the haor region. Hence, the haor region plays important role for fish production, maintaining biodiversity, meeting local and regional demand (Salauddin and Islam, 2011). However, the Kishoreganj haor region is also known for its richest SIS (Small Indigenous Fish Species) biodiversity, consisting of 30 species belonging to 7 orders and 15 families (Rownok et al., 2014).

Primary productivity is essential for fish species growth and distribution in natural water bodies. Primary production is mainly depending on nutrient concentration in aquatic environment. The variation in nutrient concentrations caused by changes in water flow and upwelling regimes of rivers is the cause of fluctuations of primary productivity (Lotze and Worm, 2002). The primary productivity describes the biological wealth of the water body, constituting a vital link in the food chain. Haor is considered to have an exceptionally higher primary productivity than other wetland habitat types (Muzaffar and Ahmed, 2007). In any aquatic ecosystem the phytoplankton works as the backbone of food chain that keeps the animals alive in aquatic environments. The phytoplankton communities of haor is very much linked with production of zooplankton and fish (Muzaffar and Ahmed, 2007). Muzaffar and Ahmed (2007) found 107 genera of phytoplankton in haor region and representing six classes. Azher et al. (2006) listed 75 plankton species (60 phytoplankton and 15 zooplankton) where Chlorophyceae and Copepoda was the most dominant groups in the Kishoreganj haor region. Fish diversity is an important index to conserve the fisheries resources in a particular region of a country. Very limited research works are available on protection of this fishery resource in Bangladesh. Therefore, the present study was conducted to assess the plankton and fish diversity in the Kishoreganj haor.

\section{Materials and Methods}

\section{Study Area}

This experiment was performed in the Kishoreganj haor (Figure 1). The area was selected considering its unique geographic location, richness of fishery resources and primary productivity and for species diversity. Total surface area of Karimganj upazila (Kishoreganj) is $200.52 \mathrm{~km}^{2}$, located in between 24022' and 24.32' north latitudes and 90.48' and 91901' east longitudes. It is bounded by Tarail and Itna upazilas in north, Nikli, Katiadi and Kishoregonj Sadar upazilas in south, Nikli and Mithamoin upazilas in east, Kishoreganj Sadar upazila in west. In Karimganj, there is a renowned fish landing station called "Chamra Bondor". Most of fish caught in the Kishorgong haor region has been landed to this station.

\section{Collection of Data}

Samples of fish were collected from the fishermen' catches landed at different stations in the study area
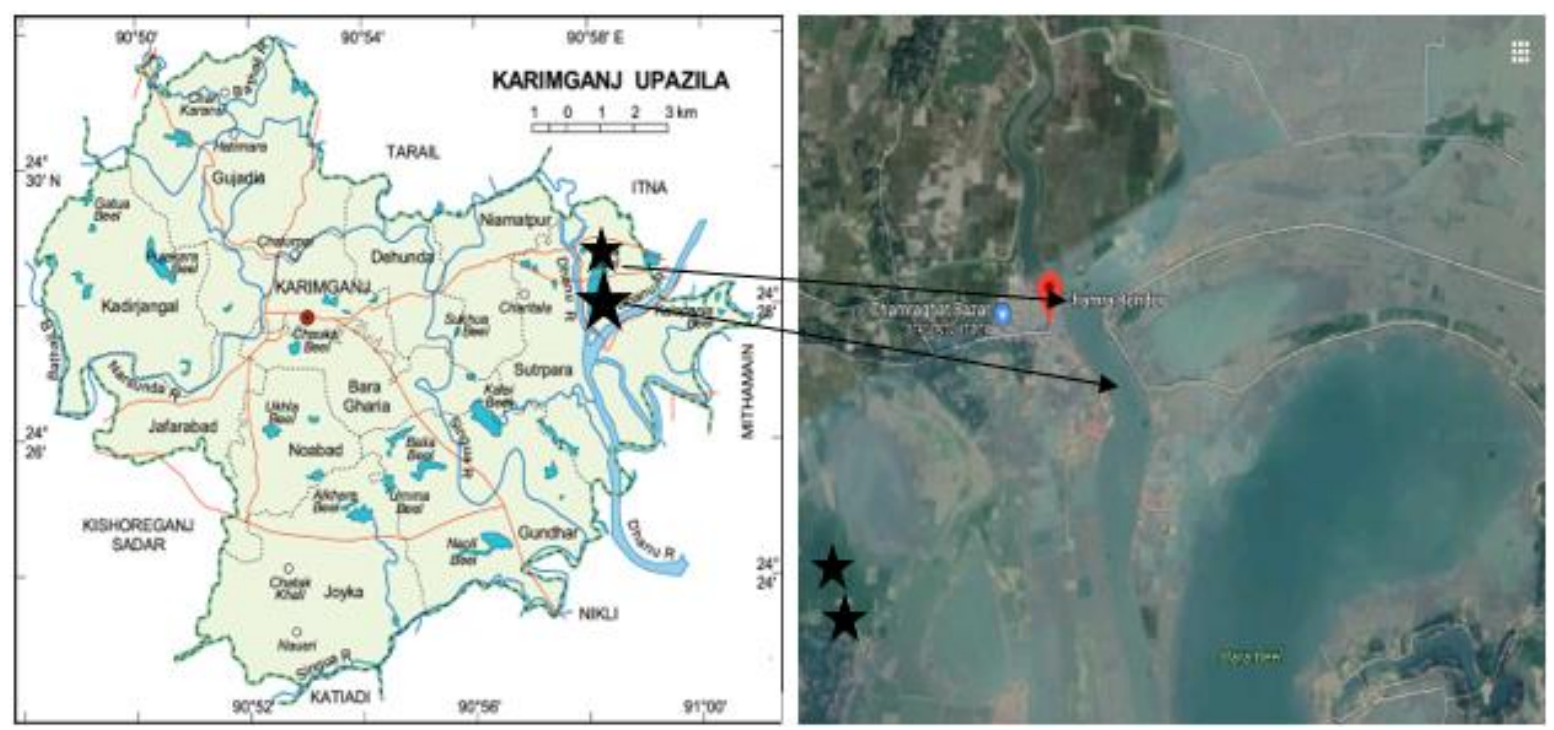

Figure 1. Map of the study area. 
and from fish markets as well. Monthly sampling was carried out from July 2017 to December 2018. Plankton samples were collected personally by monthly field visits to the study area. Historical fishing data were collected by means of interviews conducted with boat owners of commercial fishing vessels, retailers, fish traders, local people, sport fishers, riverside settlers and from the sampling area. Additional historical data was also acquired from various relevant scientific articles, reports, maps website, library, Bangladesh Fisheries Research Institute, Department of Fisheries of Bangladesh and some local NGO offices.

\section{Fish Identification}

Most of the collected fish species were identified on the spot with the help of prepared freshwater fisheries resources list, related books and IUCN red list 2015. Fish samples were also brought to the laboratory for double confirmation to identify the fish species. The fish specimens were identified based on the morphometric and meristic appearances according to Rahman (2005), Talwar and Jhingran (1991).

\section{Plankton Sampling}

Monthly plankton samples from July 2017 to December 2018 were collected from 8 different locations in the Kishoreganj haor. Sampling was performed by using a plankton net with a mesh size of $25 \mu \mathrm{m}$ and a cod end to retain the organisms. The net was towed horizontally, and the plankton samples were collected from the sub-surface layer $(0.2-0.5 \mathrm{~m})$ of the water column. Immediately after collection, all samples were preserved in $5 \%$ buffered formalin and stored in $250 \mathrm{ml}$ labeled plastic bottles. Then, the sample bottles were brought to the laboratory of Fisheries Biology and Genetics, Bangladesh Agricultural University, Mymensingh, Bangladesh for qualitative analysis under microscope.

\section{Identification of Plankton}

Collected planktons were sorted out with the help of fine brushes, needle, forceps and an inverted microscope (OPTIA B- 350 Italy). Plankton sample was picked up with plastic dropper from plastic bottle. Then sample kept on glass slide for identification. Identification of plankton was done according to Bellinger (1992). Zooplanktons were identified following the keys given by Bhouyain and Asmat (1992).

\section{Fish and Plankton Diversity Analysis}

In this study, the Shannon-Weaver diversity index (1949) was calculated for evaluating the status of fish diversity using the following formulae:

$$
H^{\prime}=-\sum_{i=1}^{R} p_{i} \ln p_{i}
$$

Where, $\mathrm{H}^{\prime}$ is the diversity index, $\mathrm{p}$ is the proportion $(n / N)$ of individuals in one particular species $(n)$ to the total number of individuals found $(N)$, and $R$ is the total number of species.

\section{Results}

\section{Fisheries Resources}

During the study period, a total of 79 fish species belonging to 27 families under 9 orders were collected from Chamra Bondor fish landing station, Karimganj, Kishoreganj, Bangladesh. Cypriniformes was the most dominant family with 31 species followed by Siluriformes (21 species), Perciformes (16 species), Clupeiformes (4 species), Anguilliformes (2 species), Beloniformes (2 species), Synbrachiformes (1 species), Tetraodontiformes (1 species) and Cyprinodontiformes (1 species) (Table 1 and Figure 2).

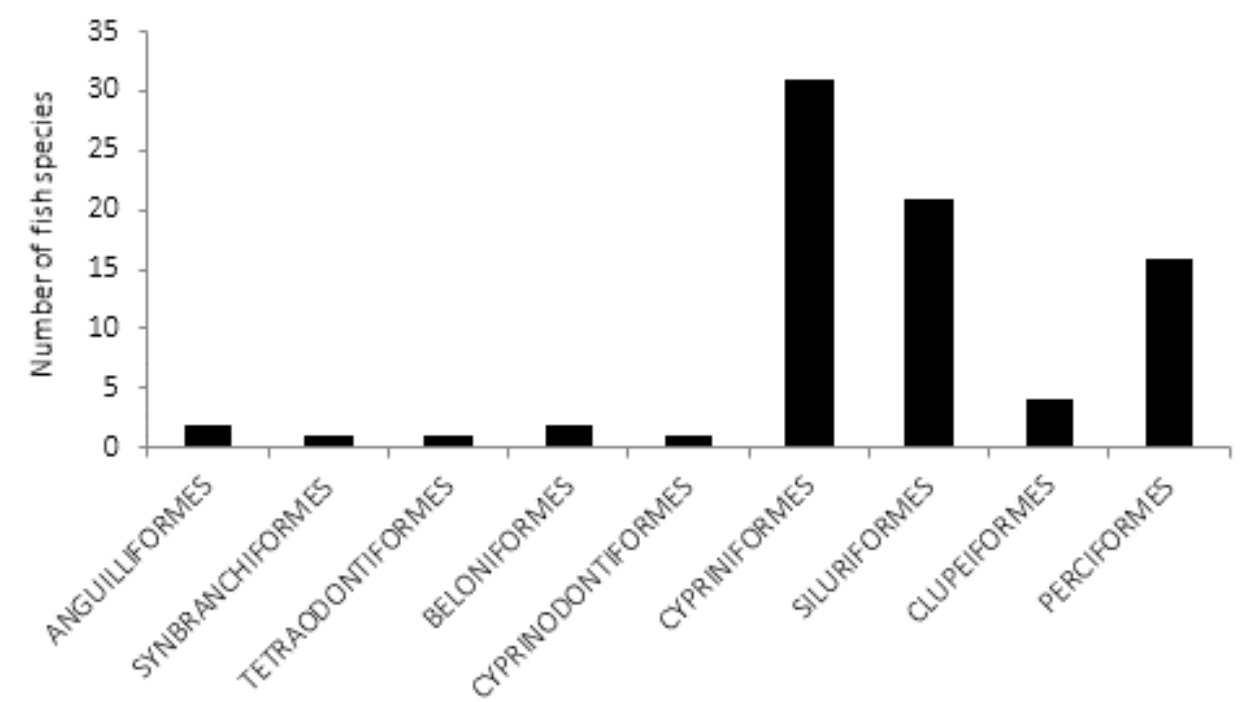

Figure 2. Species richness of different fish orders in the Kishoreganj haor during 2017-2018. 
Table 1. Monthly variations in habitation rate of sea cucumbers

\begin{tabular}{|c|c|c|c|c|c|c|c|c|}
\hline Order & Family & Scientific name & Local name & English name & $\begin{array}{c}\text { Present } \\
\text { status }\end{array}$ & $\begin{array}{l}\text { IUCN } \\
\text { status }\end{array}$ & $\begin{array}{l}\text { No. of } \\
\text { Species }\end{array}$ & $\begin{array}{c}\text { Diversity } \\
\text { index }\left(\mathrm{H}^{\prime}\right)\end{array}$ \\
\hline \multirow[t]{2}{*}{ ANGUILLIFORMES } & ANGUILLIDAE & Anguilla bengalensis & $\begin{array}{l}\text { Bamos, Bau } \\
\text { baim }\end{array}$ & $\begin{array}{c}\text { Giant Mottled } \\
\text { Eel }\end{array}$ & RA & VU & 2 & 1.1 \\
\hline & OPHICHTHIDAE & Pisodonophis boro & Nol baim & Rice-paddy Eel & $C A$ & NO & & 4.0 \\
\hline SYNBRANCHIFORMES & SYBRANCHIDAE & Monopterus cuchia & Kuiccha & $\begin{array}{l}\text { Cuchia/ } \\
\text { Gangetic } \\
\text { Mudeel }\end{array}$ & RA & VU & 1 & 1.5 \\
\hline TETRAODONTIFORMES & TETRAODONTIDAE & Tetraodon cutcutia & Potka & Pufferfish & MA & NO & 1 & 2.9 \\
\hline \multirow[t]{2}{*}{ BELONIFORMES } & BELONIIDAE & Xenentodon cancila & Kaikka & $\begin{array}{l}\text { Freshwater } \\
\text { Garfish }\end{array}$ & MA & NO & 2 & 2.8 \\
\hline & HEMIRAMPHIDAE & Hyporamphus limbatus & Subol kaikka & $\begin{array}{l}\text { Congaturi } \\
\text { Halfbeak }\end{array}$ & RA & NO & & 1.2 \\
\hline CYPRINODONTIFORMES & CYPRINODONTIDAE & Aplocheilus panchax & Kanipona & $\begin{array}{l}\text { Panchax } \\
\text { Minnow }\end{array}$ & MA & NO & 1 & 3.2 \\
\hline \multirow[t]{16}{*}{ CYPRINIFORMES } & CYPRINIDAE & Securicula gora & Naukka chela & Gora Chela & RA & NO & 31 & 1.2 \\
\hline & & Salmostoma phulo & Chela & $\begin{array}{l}\text { Finescaled } \\
\text { Razorbelly }\end{array}$ & MA & NO & & 2.7 \\
\hline & & Salmostoma bacalia & Chela & $\begin{array}{l}\text { Minnow } \\
\text { Large } \\
\text { Razorbelly } \\
\text { Minnow }\end{array}$ & MA & NO & & 2.8 \\
\hline & & Esomus danricus & Darkina & Flying Barb & RA & DD & & 1.3 \\
\hline & & Parluciosoma daniconius & Darkina & $\begin{array}{l}\text { Blackline } \\
\text { Rasbora }\end{array}$ & RA & DD & & 1.4 \\
\hline & & Barilius bendelisis & Nunchora & $\begin{array}{l}\text { Hamilton's } \\
\text { Barila }\end{array}$ & RA & EN & & 1.1 \\
\hline & & Danio devario & $\begin{array}{l}\text { Kash } \\
\text { khauri }\end{array}$ & Devario Danio & CA & NO & & 4.1 \\
\hline & & Amblypharyngodon mola & Mola & $\begin{array}{c}\text { Pale } \\
\text { Carplet }\end{array}$ & $\mathrm{CA}$ & NO & & 4.2 \\
\hline & & Osteobrama cotio & Gilachaki & Cotio & RA & EN & & 1.2 \\
\hline & & Labeo gonius & Ghonia & Kuria Labeo & RA & EN & & 1.3 \\
\hline & & Labeo calbasu & Kalbaush & Kalibasu & RA & EN & & 1.9 \\
\hline & & Labeo rohita & Rou/rui & Rohu & MA & NO & & 3.0 \\
\hline & & Labeo angra & $\begin{array}{l}\text { Karish, } \\
\text { Dirua }\end{array}$ & Angra Labeo & RA & NO & & 1.4 \\
\hline & & Labeo boggut & Nunia & Boggut Labeo & RA & $\mathrm{DD}$ & & 1.5 \\
\hline & & Cirrhinus cirrhosus & Mrigal & Mrigal Carp & MA & NO & & 3.2 \\
\hline & & Puntius sarana & $\begin{array}{c}\text { Deshi } \\
\text { sarpunti, }\end{array}$ & Olive Barb & RA & $\mathrm{CR}$ & & 1.7 \\
\hline
\end{tabular}


Puntius guganio Puntius phutunio Puntius conchonius

Titpunti

Glass Barb

Titpunti

Pigmy Barb

MA

listed

Puntius ticto

Punti

Rosy Barb

Puntius sophore

Puntius terio

Catla catla

Pita punti

Jat punti

Teri punti

Ro-spot Barb

CA

Pool Barb

Onespot Barb

Hypophthalmichthys

molitrix

Cyprinus carpio

BALITORIDAE

Nemachilus botia Nemachilus zonalternans Botia dario

COBITIDAE

Lepidocephalus guntea

Lepidocephalichthys

annandalei

Clarias batrachus

Wallago attu

CLARIIDAE

Ompok bimaculatus

Ompok pabda

HETEROPNEUSTIDAE

SCHILBEIDAE

Heteropneustes fossilis

Silonia silondia

Ailia coila

Pseudeutropius

atherinoides

Eutropiichthys vacha

Eutropiichthys murius

BAGRIDAE

Clupisoma garua
Rita rita
Aorichthys aor

Aorichthys seenghald

Hemibagrus menoda

Mystus cavasius

Mystus bleekeri

Mystus tengara

$$
\text { Catla }
$$

Silver Cap

Carpu

Common Carp

Gutum

Gutum

Bou mach

River Loach

Bengal Loach

Guntea Loach

Annandalei

Magur Woach $\quad$ Walking Catfish

Wallago

Boal

Pabda

Lali paibba

Butter Catfis

Stinging Catfish

Silond Catfish

Gangetic Ailia

Batai

Indian Potasi

Bacha

Batchwa Bacha

Indus Garua

bacha

Gagra

Ghaura

Rita, Rida

Ayer

Rita

LongWhiskered

Catfish

Kata

Giant River-

Catfish

Gang magur

Menoda Catfish Gulsha

Gangetic

Mystus

Gulsha

Day's Mystus

Bajari

Tengara Mystus

tengra 


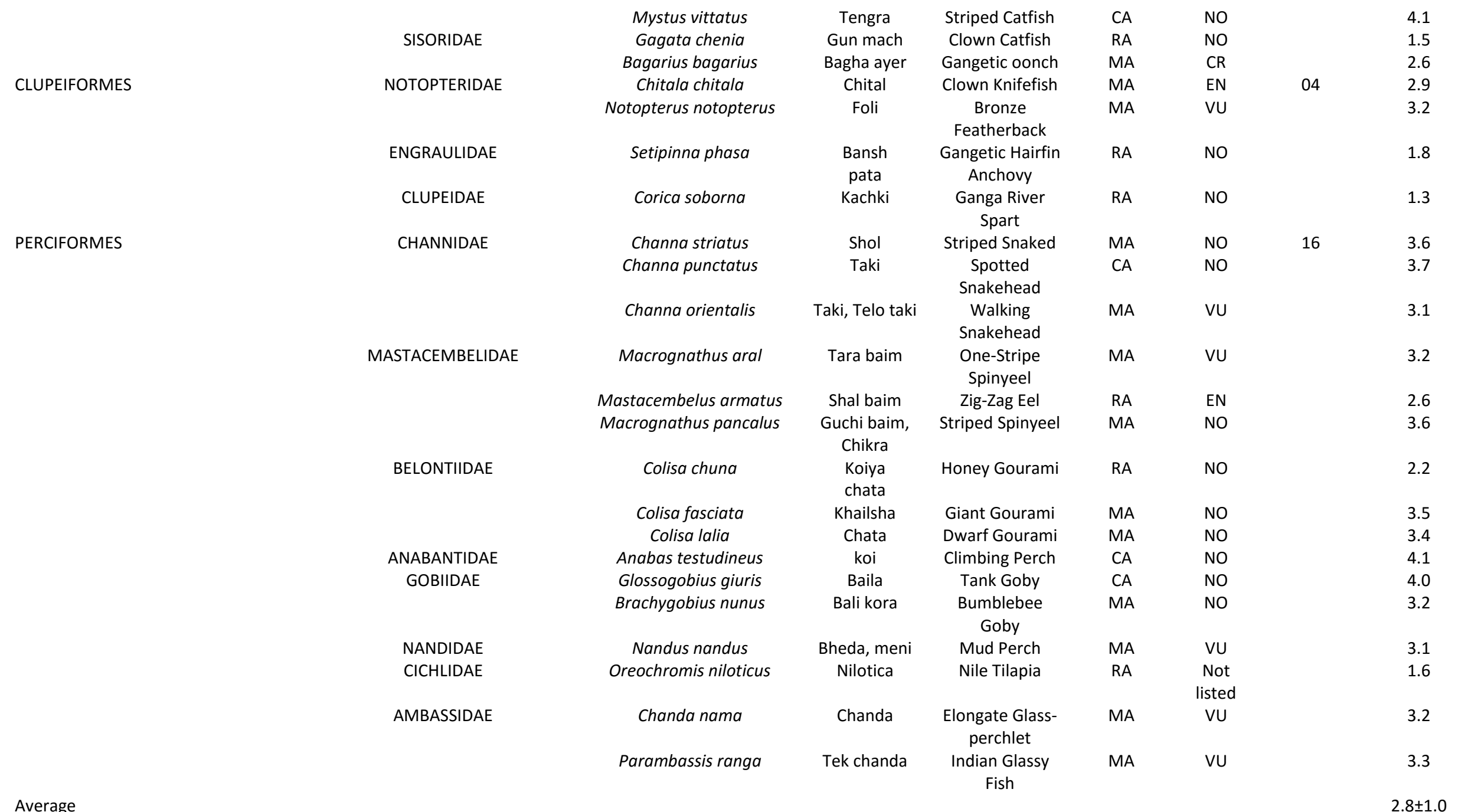

$[\mathrm{CA}=$ Commonly available species, $\mathrm{MA}=$ Moderately available species, $\mathrm{RA}=$ Rarely available species, $\mathrm{DD}=$ Data Deficient, $\mathrm{NO}=$ Not Threatened, $\mathrm{VU}=\mathrm{Vulnerable,} \mathrm{EN}=$ Endangered, $\mathrm{CR}=\mathrm{Criticall} \mathrm{y}$ Endangered.] 


\section{Fish Availability in the Kishoreganj Haor}

Comparing the present status of fish diversity with past status, it is clearly indicated that the number of fish species declined due to anthropologic factors (Figure 3).

\section{Qualitative Analysis of Phytoplankton}

A total of 23 phytoplankton species were identified under 4 classes. A total of 8 species of Bacillariaophyceae, 9 species of Chlorophyceae, 3 species of Cyanophyceae and 3 species of Euglenophyceae classes were listed from the study area (Table 2).

\section{Qualitative Analysis of Zooplankton}

A total of 3 groups of zooplankton were identified, i.e. Rotifera, Cladocera and Copepoda in Kishoreganj haor region. A total of 5 species of Rotifera, 4 species of Copepoda and 4 species of Cladocera were identified during the study period in Kishoreganj haor region. (Table 2)

\section{Diversity Indices of Fish and Plankton}

The values of diversity indices of fish were fluctuated from 1.1 to 4.3 with mean value of $2.8 \pm 1.0$. Phytoplankton diversity indices were fluctuated from 2.9 to 3.2 and 1.7 to 2.6 with mean value of $3.10 \pm 0.17$ and $2.10 \pm 0.41$ during wet and dry seasons, respectively while zooplankton diversity indices were fluctuated from 3.1 to 3.2 and 1.6 to 1.7 with mean value of $3.13 \pm 0.58$ and $1.63 \pm 0.12$ during wet and dry seasons, respectively.

\section{Discussion}

\section{Fish Diversity in the Study Area}

Freshwater fisheries sector plays an important role in the economy of Bangladesh. Diversity of fishes is the key to meet ecological balance. Fisheries resources in Kishoregong haor are characterized by a very high degree of endemism. This region is considered as home of many freshwater fish species. Among them, most of the fish are commercially important. This haor supports several rare and threatened fish species. For example, some critically endangered species like Anguilla bengalensis, Monopterus cuchia, Osteobrama cotio, Labeo gonius, Puntius sarana, Botia dario, Corica soborna, Rita rita, Bagarius bagarius, and Colisa chuna are available in Kishoreganj haor region. The diversity indices of these fish species were from 1.1 to 1.9 while the diversity index was above 4.0 for some available fish species and the average value of Kishoreganj haor was 2.8 \pm 1.0 . Khanom et al. (2016) found that the average value of diversity index of fish in Shiba river of Bangladesh was 1.86 while lqbal et al (2015) found the range of diversity index of fish in Konoskhai haor at Northeast Bangladesh was from 2.9 to 3.1. Considering the diversity index of fish, Kishoreganj haor is rich in fish. Iqbal et al. (2015) listed 83 species of fishes in the Hakaluki haor belonging to 55 genera, 28 families and 10 orders where Cypriniformes was found to the most dominant order comprising $73 \%$ followed by Siluriformes (13\%) and Perciformes (9\%). Trina et al. (2016) found 74 fish species where 8 were critically endangered, 17 were endangered, 9 were vulnerable and 39 were not threatened in Dekhar haor under Sunamganj, which is quite similar with the present

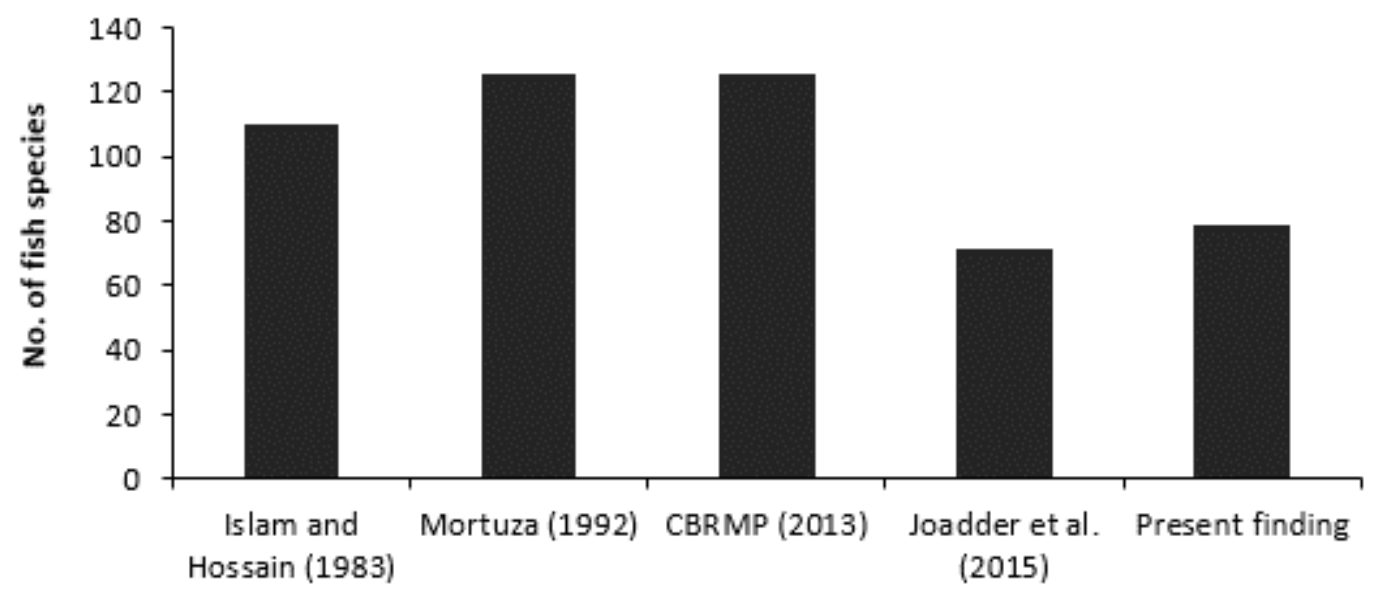

Researcher

Figure 3. Comparison between the present and past status of fish species richness in the Kishoreganj haor. 
Table 2. List of plankton genera found in the Kishoreganj haor during 2017-2018

\begin{tabular}{|c|c|c|c|c|c|}
\hline \multirow[t]{2}{*}{ Plankton } & \multirow[t]{2}{*}{ Group } & Wet season & \multirow{2}{*}{$\begin{array}{l}\text { Diversity } \\
\text { Index }\left(H^{\prime}\right)\end{array}$} & \multirow{2}{*}{$\begin{array}{c}\text { Dry season } \\
\text { Genera/species }\end{array}$} & \multirow{2}{*}{$\begin{array}{r}\text { Diversity } \\
\text { Index }\left(\mathrm{H}^{\prime}\right)\end{array}$} \\
\hline & & Genera/species & & & \\
\hline \multirow[t]{4}{*}{ Phytoplankton } & Bacillariaophyceae & $\begin{array}{l}\text { Navicula sp. } \\
\text { Gyrosigma sp. } \\
\text { Nitzschia sp. } \\
\text { Synedra sp. } \\
\text { Cyclotella sp. } \\
\text { Bacillaria sp. } \\
\text { Rhizosolenia sp. } \\
\text { Chaetoceros sp. }\end{array}$ & 3.3 & $\begin{array}{l}\text { Navicula sp. } \\
\text { Gyrosigma sp. } \\
\text { Nitzschia sp. } \\
\text { Synedra sp. } \\
\text { Bacillaria sp }\end{array}$ & 2.6 \\
\hline & Chlorophyceae & $\begin{array}{l}\text { Spirogyra sp. } \\
\text { Ulothrix sp. } \\
\text { Volvox sp. } \\
\text { Spirulina sp. } \\
\text { Chlorella sp. } \\
\text { Coleochaete sp. } \\
\text { Microspora sp. } \\
\text { Melosira sp. } \\
\text { Cosmarium sp. }\end{array}$ & 3.1 & $\begin{array}{l}\text { Spirogyra sp. } \\
\text { Ulothrix sp. } \\
\text { Volvox sp. }\end{array}$ & 2.2 \\
\hline & Cyanophyceae & $\begin{array}{l}\text { Oscillatoria sp. } \\
\text { Anabaeca sp. } \\
\text { Microcystis sp. }\end{array}$ & 3.0 & Oscillatoria sp. & 1.8 \\
\hline & Euglenophyceae & $\begin{array}{c}\text { Euglena sp. } \\
\text { Phacus sp. } \\
\text { Trachelomonas sp. }\end{array}$ & 2.9 & $\begin{array}{l}\text { Euglena sp. } \\
\text { Phacus sp. }\end{array}$ & 1.7 \\
\hline Average & & & $3.10 \pm 0.17$ & & $2.10 \pm 0.41$ \\
\hline \multirow[t]{3}{*}{ Zooplankton } & Rotifera & $\begin{array}{l}\text { Brachionus sp. } \\
\text { Keratella sp. } \\
\text { Filinia sp. } \\
\text { Asplanchna sp. } \\
\text { Polyarthra sp. }\end{array}$ & 3.2 & $\begin{array}{l}\text { Brachionus sp. } \\
\text { Keratella sp. }\end{array}$ & 1.7 \\
\hline & Cladocera & $\begin{array}{c}\text { Moina sp. } \\
\text { Daphnia sp. } \\
\text { Bosmina sp. } \\
\text { Diaphanosoma sp. }\end{array}$ & 3.1 & $\begin{array}{l}\text { Moina sp. } \\
\text { Daphnia sp. }\end{array}$ & 1.6 \\
\hline & Copepoda & $\begin{array}{l}\text { Cyclops sp. } \\
\text { Diaptomus sp. } \\
\text { Macrocyclops sp. } \\
\text { Mesocyclops sp. }\end{array}$ & 3.1 & $\begin{array}{c}\text { Cyclops sp. } \\
\text { Diaptomus sp. }\end{array}$ & 1.7 \\
\hline Average & & & $3.13 \pm 0.58$ & & $1.63 \pm 0.12$ \\
\hline
\end{tabular}

findings. Islam et al. (2008) have recorded 108 species under 29 families of 10 orders from Tanguar Haor. Moreover, Pandit et al. (2015) listed 84 fish species from Dekhar haor of Sunamganj. Most of their findings are very similar to the present study. In the present study, the abundance of nandina (L. nandina), elong (Bengala elanga), batasi (Batasio tengana), rita (Rita rita), kajoli (Ailia unctate), garua (Clupisoma garua) and shilong (Silonia silondia) were found to be very low probably due to over exploitation and habitat degradation. Fish population is decreasing due to over exploitation and other anthropologic activities; and habitats of the Meghna, Laukhati and Galachipa rivers are degraded as well as livelihood of fishermen is below standard (Rahaman et al. 2019 and 2020; Hossain et al. 2018). It is clearly indicated that the abundance of fishes is decreased sharply. Probably because, fishermen capture a large number of fish specimens by small mesh sized nets in Kishoreganj haor. The fish species diversity was also decreased by rising temperature in Kishoreganj haor region. The abundance and distribution of fish species is controlled by water quality and primary productivity in rivers of Kishoreganj. However, fish availability has also been reduced for overfishing effort and blocking fish migration route.

\section{Primary Productivity in the Kishoreganj Haor Region}

Plankton plays an important role as a primary producer in haor ecosystem and it is an important source of food for fish. Phytoplankton is an important primary producer and constitutes the basis of nutrient cycle of an ecosystem (Singh et al., 2013). Plankton growth, biomass and productivity are influenced by the nutrients, light and water temperature. Phytoplankton and zooplankton abundance varies from one water system to another. In the present study, a total 23 phytoplankton genera under 4 groups was identified. 
Bacillariophyceae, Chlorophyceae were the dominant and common group in the present study area. Other recorded common genera were: Navicula sp., Gyrosigma sp., Nitzschia sp., Synedra sp., Cyclotella sp., Bacillaria sp., Rhizosolenia sp., Spirogyra sp., Ulothrix sp., Volvox sp., and Euglena sp.. Azher et al. (2006) listed 60 genera of phytoplankton in Kishoreganj haor region where Chlorophyceae was the major group. Ahsan et al. (2012) listed a total 19 taxa (32.76\%) of phytoplankton where Chlorophyceae (7 taxa) was the most dominant group in the Meghna river. In addition, Rahaman et al. (2016) and Rahaman et al. (2018) reported data quite similar to the present study. In Kishoreganj haor region, Nitzschia sp., Synedra sp. and Oscillatoria sp. were found in wet and dry seasons. These species indicate the pollution of water in the study area (Singh et al., 2013). In addition, Microcystis sp., and Euglena sp. were also found in the study area, which indicate the eutrophic condition in the water body (Singh et al., 2013). In Kishoreganj haor, phytoplankton diversity indices were fluctuated from 2.9 to 3.2 and 1.7 to 2.6 with mean value of $3.10 \pm 0.17$ and $2.10 \pm 0.41$ during wet and dry seasons, respectively. It indicated that Kishoreganj haor was a productive water body during study period. Ekhator and Alika (2016) reported the phytoplankton diversity of the Osse river, Edo State, Nigeria was ranged from 1.8 to 3.4. Similarly, Miao (2019) found the fluctuation of phytoplankton from 1.44 to 3.08 in the Backshore Wetland in Shanghai, China.

Zooplanktons do not depend directly on nutrients to survive. Zooplanktons play important roles in food chain by linking primary producers and higher trophic levels (Xu et al., 2001). In the present study, a total of 12 zooplankton genera under 3 groups (Rotifera, Cladocera and Copepoda) were identified. Rotifera (Brachionus sp., Keratella sp., Filinia sp., Asplanchna sp., and Polyarthra sp.) was the dominant group in the present study area. Other recorded common species were Brachionus sp., Keratella sp., Moina sp., Daphnia sp., Bosmina sp., and Cyclops sp.. Ahmed et al. (2003) was also found quite similar results mentioned 13 zooplankton genera in the Meghna river. In additiona, 15 genera (Daphnia sp., Ceriodaphnia sp., Diaphanosoma sp., Bosmina sp., Moina sp., Cyclops sp., Diaptomus sp., Brachionus sp., Keratella sp., Filinia sp., Tiichocera sp., Filinia sp., Lecane sp. and Polyarthra sp.) of zooplankton were listed in Kishoreganj haor (Rahman et al., 2005 and Azher et al., 2006) . In the present study, Moina sp. and Cyclops sp. were also found in both dry and wet season, which indicate the pollution of water body in the Kishoreganj haor (Jha and Barat, 2003). In Kishoreganj haor, zooplankton diversity indices were fluctuated from 3.1 to 3.2 and 1.6 to 1.7 with mean value of $3.13 \pm 0.58$ and $1.63 \pm 0.12$ during wet and dry seasons, respectively. Ismail and Zaidin (2015) found that the zooplankton diversity indices were changed from 1.07 to 1.21 in different types of water bodies in Indonesia. These results indicated that Kishoreganj haor was rich with zooplankton during the study period.

\section{Conclusion}

Considering the data of the present study, it can be concluded that the fish and plankton diversity in Kishoregonj haor is good even though abundance of some fish species are declining day by day. The use of destructive nets, indiscriminate fishing, ban of fishing during breeding season will be the effective actions to save the biodiversity in Kishoregonj haor.

\section{Acknowledgements}

Authors acknowledge to the Project Implementation Unit, National Agricultural Technology Program-Phase II Project (NATP-2), Bangladesh Agricultural Research Council (BARC), Farmgate, Dhaka1215, Bangladesh for funding the project (no. CRG-718).

\section{References}

Ahmed, K. K. U., Ahamed, S. U., Hossain, M. R. A., Ahmed, T., and Barman, S. (2003). Quantitative and qualitative assessment of plankton: some ecological aspect and water quality parameters of the river Meghna, Bangladesh. Bangladesh Journal of Fisheries Research., 7(2): 131-140.

Ahmed, M. (2012). Community led framework for estimation of sustainable exploitation level of fish and reeds in Tanguar Haor. Community Based Sustainable Management of Tanguar Haor Project-II, IUCN, SDC (Swiss Agency for Development and Cooperation), 1-30.

Ahsan, D. A., Kabir, A. N., Rahman, M. M., Mahabub, S., Yesmin, R., Faruque, M. H. and Naser, M. N. (2012). Plankton composition, abundance and diversity in Hilsa (Tenualosa ilisha) migratory rivers of Bangladesh during spawning season. Dhaka University Journal of Biological Sciences, 21(2):177-189.

Azher, S. A., Khanom, F., and Dewan, S. (2006). Impacts of fish sanctuaries on the production and diversity of plankton on beels of haor region in Bangladesh. Bangladesh Journal of Fisheries Research, 10(2): 139-150.

Bellinger, E. G. (1992). A key to common algae: freshwater, estuarine and some coastal species. The institution of water and environmental management, London, U.K. 138.

Bhouyain, A. M., and Asmat, G. S. M. (1992). Freshwater zooplankton from Bangladesh. Gazi Publishers, Dhaka, Bangladesh. 32-151.

Chowdhury, M. U. I. (2016). Wetland-community resilience to flash flood hazards (Bonna) in Sunamganj district, Bangladesh.

Ekhator, O., and Alika, F. (2016). Phytoplankton diversity indices of Osse river, Edo State, Nigeria. Ife Journal of Science, 18(1): 63-84.

Hanif, M. A., Tabassum, A., Hauque, A. M., Hossain, M. R., Jahan, D. S., and Debnath, A. K. (2015). Determination of location quotient (LQ) of districts of Bangladesh based on level of urbanization and their regionalization to study the regional disparities based on indicators of urban area of Bangladesh. European Academic Research, 2:1671-1692.

Hossain, M. J., Sarker, M. J., Uddin, M. N., Islam, A., Tumpa, I. J., and Hossain, Z. (2018). Macrobenthos presence in the 
estuarine waters of the Meghna river, Ramghati, Laksmipur, Bangladesh. World Applied Sciences Journal, 36: 598-604.

https://doi:10.5829/idosi.wasj.2018.598.604

Hussain, M. M., and Salam, M. A. 2007. Basic Service Delivery Advocacy: Review Report. Development Wheel (DEW), Dhaka.

Iqbal, M. M., Kanon, M. H., Hossain, M. A., Hossain, A., Nasren, S., Islam, M. J., and Rahman, M. A. (2015). Diversity of indigenous fish species in Konoskhaihaor, Northeast Bangladesh. Punjab University Journal of Zoology, 30(2): 73-79.

Iqbal, M. M., Nasren, S., and Hossain, M. A. A. M. M. (2015). Fish assemblage including threatened species in Hakaluki haor, Sylhet, Bangladesh. Journal of Aquaculture in The Tropics, 30 (3-4): 233-246.

Islam, K. A., Bashar, M. A., and Ali, M. S. (2008). Diversity of fish fauna in Tanguar haor system. Bangladesh Journal of Zoology, 36(2): 167-174.

Ismail, A. H., Zaidin, S. A. (2015). A comparative study of zooplankton diversity and abundance from three different types of water body. 2nd International Conference on Agriculture, Environment and Biological Sciences (ICAEBS'15) August 16-17, 2015, Bali, Indonesia.

IUCN (2015) Red List of Threatened Species. [http://www.iucnredlist.org/apps/redlist/search].

Jha, P., and Barat, S. (2003). Hydrobiological study of Lake Mirik in Darjeeling, Himalaya. Journal of Environmental Biology, 24(3): 339-344.

Khanom, D. A., Khatun, T., Jewel, M. A. S., Hossain, M. D., and Rahman, M. M. (2016). Present status of fish biodiversity and abundance in Shiba river, Bangladesh. University Journal of Zoology Rajshahi University, 35: 7-15.

Lotze, H. K., and Worm, B. (2002). Complex interactions of climatic and ecological controls on macroalgal recruitment. Limnology and Oceanography, 47(6): 17341741. https://doi.org/10.4319/lo.2002.47.6.1734

Miah, M. R. (2013). Enhancing food security through acclimatized species domestication in the haor region. Journal of Advanced Research, 2(1): 49-65.

Miaoa, X., Wanga, S., Liua, M., Maa, J., Hua, J., Lia, T., and Chena, L. (2019). Changes in the phytoplankton community structure of the Backshore Wetland of Expo Garden, Shanghai from 2009 to 2010. Aquaculture and Fisheries, 4: 198-204.

Muzaffar, S. B., and Ahmed, F. A. (2007). The effects of the flood cycle on the diversity and composition of the phytoplankton community of a seasonally flooded Ramsar wetland in Bangladesh. Wetlands Ecology and Management, 15(2): 81-93. https://doi.org/ 10.1007/s11273-006-9014-6.

Nowreen, S., Murshed, S. B., Islam, A. S., Bhaskaran, B., and Hasan, M. A. (2015). Changes of

rainfall extremes around the haor basin areas of Bangladesh using multi-member ensemble RCM. Theoretical and Applied Climatology, 119(1-2): 363-377.

https://doi.org/10.1007/s00704- 014-1101-7

Pandit, D., Kunda, M., Harun-Al-Rashid, A., Sufian, M.A., and Mazumder, S.K. (2015). Present status of fish biodiversity in Dekhar haor, Bangladesh: a case study. World Journal of Fish and Marine Sciences, 7(4): 278-287. https://doi.org/10.5829/idosi.wjfms.2015.7.4.95127

Rabby, T. G., Alam, G. M., Mishra, P. K., Hoque, K. E., and Nair, S. (2011). Different economic and policy perspectives in micro population for sustainable development: A study of the Haor livelihood in Bangladesh. African Journal of Business $\quad$ Management., 5(6): 2475-2492. https://doi.org/10.5897/AJBM11.224

Rahaman, M. J., Ema, N. S., Hossain, M. S., Rahman, M. M., and Hossain, Z. (2019). Effects of climate change on fisheries biodiversity of the Meghna, Laukhati and Galachipa river in Bangladesh. EurAsian Journal of Biosciences, 13: 1-12.

Rahaman, M. J., Hossain, M. S., Rahman, M. M., and Hossain, Z. (2020). Impacts of climate change on livelihood of the fishers' at the Meghna, Laukhati and Galachipa river in Bangladesh. Asian Journal of Medical and Biological Research, 6(1): 81-92. http://doi: 10.3329/ajmbr.v6i1.46482

Rahman, A. K. A. (2005). Freshwater Fishes of Bangladesh. 2nd Ed. Zoological Society of Bangladesh, Dhaka, Bangladesh, 263.

Rahman, M. A., Haider, M. I., Khan, M. H., Rahman, M. K. and Mahmud, Y. 2018. Mass Mortality of Fishes: A catastrophic phenomena at Haor regions in Bangladesh, Bangladesh Journal of Fisheries Research,17(1-2): 101106.

Rahman, M. M., Chowdhury, P. and Islam, M. S. 2016. Livelihood status of fishers' community of Eshulia Beel at Gouripur upazila under Mymensingh district. International Journal of Fisheries and Aquatic Studies, 4(3): 543-547.

Rownok Jahan, M., Quaiyum, A., Sarker, B. S., Hossain, M. B., Jaman, K. K. B., and Rahman, S. (2014). Biodiversity and seasonal abundance of small indigenous fish species (SIS) in the rivers and adjacent beels of Karimganj (Kishoreganj, Bangladesh). Asian Journal of Animal Science, 8(2): 38-46.

Salauddin, M., and Islam, A. K. M. S. (2011). Identification of land cover changes of the haor area of Bangladesh using Modis Images. 3rd International Conference on Water and Flood Management (ICWFM-2011).

Sarma, P. K. (2010). Scenario of haor vulnerabilities and other obstacles for sustainable livelihood development in Nikli upazila. Journal of the Bangladesh Agricultural University, 8(2): 283-290.

Sarma, P.K., Sarker, S., and Hossain, M. A. (2010). To Encourage Rural Employment and Income Through Dry Fish (Shutki) Processing Farming Household in Kishoregonj District. Bangladesh Journal of Agriculturist, 3(2): 141-145.

Shannon, C.E., and Weaver, W. (1949). The Mathematical theory of communication. Urbana, IL: University of Illinois Press. 54p.

Singh, U. B., Ahluwalia, A. S., Sharma, C., Jindal, R., and Thakur, R. K. (2013). Planktonic indicators: a promising tool for monitoring water quality (early-warning signals). Ecology Environment Conservation, 19(3): 793800.

Talwar, P. K., and Jhingran A. G. (1991). Inland Fishes of India and Adjacent Countries. Vol. 1-2, Oxford and IBH Publishing Co. Pvt. Ltd., New Delhi, 1097.

Trina, B. D., Roy, N. C., Das, S. K., and Ferdausi, H. J. (2016). Socioeconomic Status of Fishers' community At Dekhar Haor in Sunamganj District of Bangladesh. Journal of the Sylhet Agricultural University, 2(2): 239-246.

Xu, F., Tao, S., Dawson, R. W., Li, P., and Cao, J. (2001). Lake ecosystem health assessment: indicators and methods. Water Research, 35: 3157-3167.

https://doi.org/10.1016/S00431354(01)00040-9 